\title{
Health Care Utilization by Children with Disabilities and Evaluation of Factors Affecting Caregiver Satisfaction
}

\author{
Yasin Karatas (Corresponding author) \\ Recep Tayyip Erdogan University Faculty of Medicine Training and Research Hospital, \\ Department of Pediatrics, Rize, Turkey \\ E-mail: dr.yasinkaratas@hotmail.com \\ Yasin Yildiz \\ Recep Tayyip Erdogan University Faculty of Medicine Training and Research Hospital, \\ Department of Pediatrics, Rize, Turkey \\ E-mail: dilayram@hotmail.com \\ Kader Semra Karatas \\ Recep Tayyip Erdogan University Faculty of Medicine Training and Research Hospital, \\ Department of Psychiatry, Rize, Turkey \\ E-mail: drsemraidil@gmail.com
}

\begin{abstract}
Aim: Health care is lacking for some level of mental disability for various reasons. The aim of this study was to examine health care utilization by individuals with severe disabilities applied to the health committee of a university hospital and to examine the factors that determine caregiver satisfaction by assessing their burden of care, quality of life, and level of burnout.
\end{abstract}

Methods: Of the 840 disabled individuals who applied to Recep Tayyip Erdoğan University Faculty of Medicine Training and Research Hospital, Rize, Turkey between January 2016 and 2019, 48 with severe disability caregivers were included in the study. Their sociodemographic information, level of health care, and caregiver satisfaction were analyzed using sociodemographic data forms. The Zarit Caregiver Burden Scale, Maslach Burnout Inventory, and Family Quality of Life Scale were used to assess the caregiver data.

Results: More than half of the 48 children with severe disabilities were male (52.1\%).Disabled females and female caregivers appeared to increase the level of emotional burnout of caregivers according to Maslach Burnout Inventory and Family Quality of Life Scale (p:0.01, p:0.05, p:0.02, p:0.03). Groups receiving home care was found with satisfaction. Disabled children and caregivers who were living within an urban area have significant differences with Maslach Burnout Inventory Personal Success (p:0.03).

Conclusion: Disability is more of a risk for males. The sex of the disabled individual and caregiver were factors that affected caregiver burnout. Home care services increases caregiver satisfaction. Living within an urban area decreased the level of burnout on caregiver.

Keywords: Caregiver burden, caregiver satisfaction, children disabilities, health care, family quality

\section{DOI: $10.7176 / \mathrm{JHMN} / 83-01$}

\section{Introduction}

Disability defines as a disadvantageous situation that occurs in an individual resulting from a deficiency or impairment and limits his/her abilities to perform ordinary activities based on sex, age, and social and cultural status $(1,2)$. While $15.3 \%$ of the world's population have a disability, (3) $12.3 \%$ of the total population of Turkey are disabled (4). According to research by the Turkish Statistical Institute (2010) on the issues of disabled individuals, $25.1 \%$ of children $0-6$ years old have some kind of speech disability, $9.6 \%$ are hearing impaired, $7.4 \%$ are mentally impaired, $3.7 \%$ have a physical disability, $3.7 \%$ are multi-handicapped, $3.6 \%$ have a chronic disease, $2 \%$ are emotionally unstable, and $1.4 \%$ are visually impaired $(5,6)$. 
Individuals with disabilities usually need support not only within their personal and society living space but also receiving health care, and this support is mostly provided by their families, institutions providing community services, and public institutions (7-9). Patient satisfaction should be affected more easily access health care services and be provided with regular care $(5,7)$. The extent to which patients are satisfied depends on meeting their family's and their expectations or their perceptions of the provided services (3). Sex, age, type of disability, whether on social security, place of residence, and communication with a caregiver (if needed) of individuals with disabilities are some of the factors that affect their satisfaction with health care services (8). Interaction of the caregiver with the disabled person, coping attitudes towards adaptation are important in coping with problems, various psychiatric disorders may occur in their disability (9-14). This may prevent the disabled individuals and their families from establishing and maintaining healthy relationships within society, increase the caregiver's burden, and affect her or his quality of life (15-17). Most studies have focused on measuring quality of life of disabled individual; however, the quality of life of the family members and caregivers has recently drawn attention (18). Having a child with a disability, regardless of the level and type, causes psychological, social, and economic problems and creates additional responsibilities. Caregivers may experience physical and emotional burnout when they take responsibility for a long period. Therefore, it is necessary to act carefully because burnout can affect how a caregiver functions in private, social, and professional life (19-21).

The aim of the government's material and nonmaterial support to the families of a disabled individual is to provide them with multiple, holistic, and functional services and ensure satisfaction with this support and their increased personal functionality. There are very few studies on the health care services provided in Turkey to individuals with severe disabilities and parent satisfaction with these services. The aim of this study was to examine the utilization of health care by individuals with severe disabilities who applied to the health committee of the Recep Tayyip Erdoğan University Faculty of Medicine Training and Research Hospital to assess the burden on caregivers, their quality of life, and the level of caregiver burnout and to determine the factors that affect caregiver satisfaction with the health care offered according to their expectations and needs.

\section{Materials and Methods}

\section{Type of research and approval}

This was a cross-sectional epidemiological study that was approved by the ethics committee (approval no. 40465587-02) of local ethics committee no. 2019/2 dated January 2, 2019.

\section{Data collection, universe, and sample}

Eight hundred forty individuals $<18$ years old applied to the Recep Tayyip Erdoğan University Faculty of Medicine Training and Research Hospital, Rize between January 2016 and 2019 to have their disability evaluated. According to the Official Gazette No. 28603 (March 30, 2013), the criteria for determining disability, its classification, and the medical report to be provided to the disabled individuals were used to assess the individuals who applied. Of these, 62 were diagnosed with severe disabilities, and these who had applied for and either did or did not have home care services were contacted by phone. Of the 62 individuals, 12 did not want to participate in the study, leaving 50 volunteers to be included. These individuals were given complete information about the study and submitted a signed informed consent form. The researcher interviewed the caregivers for $1.0-1.5 \mathrm{~h}$ to first gather sociodemographic data and then assess them based on their answers to the Zarit Caregiver Burden Scale, Family Quality of Life Scale, and Maslach Burnout Inventory. Two of the caregivers dropped out the study because they did not fill out the data form and the scales as required.

\section{Data collection tools}

Sociodemographic data form

The data collection questionnaire was prepared from information on caregivers based on relevant literature and comprised 26 items separated into information about the child and information about the parents. Information about the child comprised sex, age, age at diagnosis of disability onset, reason for disability, having a special room, and whether he or she received social security; the information on the parents included age, educational background, employment status, profession, number of living children, whether they received family social security, whether they could allot enough time for the child, whether they received home care services, whether they were satisfied with home care services, and determination of their satisfaction through open-ended questions. 
Zarit Caregiver Burden Scale

In 1980, Zarit, Reever, and Bach-Peterson developed this scale to evaluate the stress levels of the caregivers of disabled individuals. Turkish validity and reliability of the scale was conducted by İnci and Erdem. The scale comprised 22 statements for determining the effect that caregiving has on an individual's life. The answers were evaluated using a five-point Likert scale with choices of never, rarely, sometimes, frequently, and always, with numerical ratings between 0 and 4 , respectively. The scores and their interpretation were as follows: 88-61, severe burden; 60-41, moderate to severe burden; 40-21, low to moderate burden; and <21, low/none. A higher score indicated additional problems. The maximum score was 88 and the minimum was 0 with a Cronbach's alpha internal consistency coefficient of 0.95 (22).

\section{Maslach Burnout Inventory}

The Maslach Burnout Inventory, developed by Maslach and Jackson (1981) and named Maslach in the literature, comprised 22 items and 3 subscales. This burnout inventory was scored using a seven-point Likert scale. The emotional burnout subscale consisted of nine items, the depersonalization scale consisted of five items, and the personal failure scale consisted of eight items. These were scored between 1 (never) and 7 (always); however, after changes were made to the scale, which was translated into Turkish by Ergin (1992), the scores were dropped to five points between 0 (never) and 4 (always). This inventory was adapted by Duygun (2001) to evaluate the burnout of mothers who had children with mental disabilities and its validity and reliability were determined. Emotional burnout and depersonalization subscales evaluated burnout on the following two levels: emotional burnout and personal success. Internal consistency coefficients of the subscales were between 0.65 and 0.83 (19).

\section{Family Quality of Life Scale}

The Family Quality of Life Scale was applied to relatives of disabled patients and comprised 37 items. After being examined and regulated, a study was conducted to test this scale, which consisted of the following four subscales: physical health, psychological health, social anxieties, and spiritual wellbeing. The test-retest reliability results of the study were $r=0.89$ and the internal consistency alpha value was $r=0.69$. Factor analysis was approved for the four subscales. The items were scored from 0 to 10 , with 10 signifying the best and 0 the worst. Total and subscale scores were evaluated, and higher scores indicated a higher quality of life (23).

\section{Statistical analyses}

The data were analyzed using SPSS ver. 24 (IBM Corp., Armonk, NY, USA). Descriptive statistics were given as the frequency distribution, arithmetic means, and standard deviations. Distribution characteristics of continuous variables were analyzed using the Kolmogrov-Smirnov test. Continuous variables were compared using categorical variables and the Mann-Whitney U and Kruskal-Wallis $\mathrm{H}$ tests. A chi-squared test was used to analyze the correlation between two categorical variables. A type 1 error margin ( $\mathrm{p}$ value) was taken as 0.05 in all analyses.

\section{Results}

Of the participants with disabilities, $47.9 \%$ were female and $52.1 \%$ were male. The ages of $54.3 \%$ of the participants ranged from 6 to 10 years with a mean of $8.87 \pm 3.84$. Of the participants, $70.8 \%$ were diagnosed in their first year of life. Physical impairment was the most frequent disability (37.5\%), and $37.5 \%$ received home care. Of all the participants, $68.8 \%$ were female, all their caregivers were their mothers with a mean age of $39.08 \pm 8.08$ years. Of the caregivers, $8.3 \%$ were divorced while caring for a disabled child. Of the parents, $66.7 \%$ lived in an urban area (Table-1).

According to the Caregiver Burden Scale, $79.2 \%$ reported little or no burden. On the Family Quality of Life Scale, the psychological health subscale mean score was $48.9 \pm 13.0$ and the spiritual subscale mean score was $44.5 \pm 9.3$. In the Maslach Burnout Inventory, the mean score of the personal success subscale was $32.4 \pm 4.8$ and that of the emotional burnout subscale was $22.6 \pm 6.9$ (Table 2).

When comparing the sociodemographic data and clinical scales, a positive significant difference was found between the Family Quality of Life Scale and psychological health subscale as the age of the disabled individuals increased $(\mathrm{p}=0.01)$. A significant difference was found between female individuals with disabilities and female caregivers and the Maslach Burnout Inventory emotional burnout subscale and Family Quality of Life Scale psychological health subscale ( $\mathrm{p}=0.01, \mathrm{p}=0.05$, $p=0.02, p=0,03$, respectively). There was a significant difference between the place of residence in an urban setting and unemployment of caregivers and Maslach Burnout Inventory personal success subscale ( $\mathrm{p}=0.03, \mathrm{p}=0.02$, respectively ) (Table 3 ). 
Table 1. Sociodemographic attributes of disabled individuals and their caregivers

\begin{tabular}{|c|c|c|c|c|c|c|c|}
\hline \multicolumn{5}{|c|}{ Care receiver } & \multicolumn{3}{|c|}{ Caregiver } \\
\hline & & $\mathrm{n}$ & $\%$ & & & $\mathrm{n}$ & $\%$ \\
\hline \multirow{2}{*}{ Sex } & Female & 23 & 47.9 & \multirow{2}{*}{ Sex } & Female & 33 & 68.8 \\
\hline & Male & 25 & 52.1 & & Male & 15 & 31.2 \\
\hline \multirow{4}{*}{$\begin{array}{l}\text { Age range } \\
\text { (years) }\end{array}$} & $1-5$ & 9 & 18.7 & \multirow{4}{*}{ Marital status } & Single & 5 & 10.4 \\
\hline & $6-10$ & 26 & 54.3 & & Married & 39 & 81.3 \\
\hline & $11-14$ & 8 & 16.8 & & Divorced & 4 & 8.3 \\
\hline & $15-18$ & 5 & 10.2 & & & & \\
\hline \multirow{5}{*}{$\begin{array}{l}\text { Age at } \\
\text { Diagnosis }\end{array}$} & 3-6 months & 24 & 50 & \multirow[b]{2}{*}{ Education level } & Primary school & 19 & 39.6 \\
\hline & 7-12 months & 10 & 20.8 & & $\begin{array}{l}\text { High school and } \\
\text { higher }\end{array}$ & 29 & 61.4 \\
\hline & 13-24 months & 7 & 14.6 & \multirow{3}{*}{ Profession } & Employed & 13 & 27.1 \\
\hline & 24-36 months & 5 & 10.4 & & Unemployed & 38 & 47.9 \\
\hline & $\geq 37$ months & 2 & 4.2 & & Quit job & 12 & 25 \\
\hline \multirow{4}{*}{ Diagnosis } & Speech disorder & 1 & 2.1 & \multirow{2}{*}{$\begin{array}{l}\text { Mean age (year) } \\
\text { (mean } \pm \text { SD) }\end{array}$} & & \multirow{2}{*}{\multicolumn{2}{|c|}{$39.08 \pm 8.08$}} \\
\hline & Mental disability & 13 & 27.1 & & & & \\
\hline & Physical disability & 18 & 37.5 & \multirow{2}{*}{$\begin{array}{l}\text { Income level (TRY) } \\
\text { (mean } \pm \text { SD) }\end{array}$} & & \multirow{2}{*}{\multicolumn{2}{|c|}{$3145.93 \pm 2206.06$}} \\
\hline & Chronic disease & 16 & 33.3 & & & & \\
\hline \multirow{2}{*}{$\begin{array}{l}\text { Home care } \\
\text { services }\end{array}$} & Yes & 18 & 37.5 & \multirow{2}{*}{ Social Security } & Yes & 43 & 89.6 \\
\hline & No & 30 & 62.5 & & No & 5 & 10.4 \\
\hline \multirow{2}{*}{ Special room } & Yes & 27 & 56.3 & \multirow{2}{*}{ Place of Residence } & City center & 16 & 33.3 \\
\hline & No & 21 & 43.7 & & Village & 32 & 66.7 \\
\hline \multicolumn{2}{|c|}{ Age (year) (mean \pm SD) } & & $\begin{array}{l}7 \pm \\
4\end{array}$ & & & & \\
\hline
\end{tabular}

Notes: $n$, number of patients; SD, standard deviation; TRY, Turkish Lira.

Table 2. Assessment of clinical scales

\begin{tabular}{llcc}
\hline & & $\mathbf{n}$ & $\%$ \\
\hline Caregiver Burden Scale & Little/none & 38 & 79.2 \\
& Low to moderate & 10 & 20.9 \\
& Moderate to severe & 0 & 0 \\
\hline & Severe burden & 0 & $16.6 \pm 7.8$ \\
\hline Caregiver Burden Scale General average & (mean \pm SD) & \multicolumn{2}{c}{} \\
\hline Maslach Burnout Inventory (mean \pm SD) & Emotional burnout & $22.6 \pm 6.9$ \\
\cline { 2 - 3 } & Personal success & $32.4 \pm 4.8$ \\
\hline Quality of Life & Physical health & $26.7 \pm 9.6$ \\
\cline { 2 - 3 } $\begin{array}{l}\text { Scale } \\
\text { (mean } \pm \text { SD) }\end{array}$ & Psychological Health & $48.9 \pm 13.0$ \\
\cline { 2 - 3 } & Social anxiety & $42.5 \pm 14.6$ \\
\cline { 2 - 3 } & Spiritual & $44.5 \pm 9.3$ \\
\hline
\end{tabular}


Table 3. Comparison of clinical scales and sociodemographic data 1

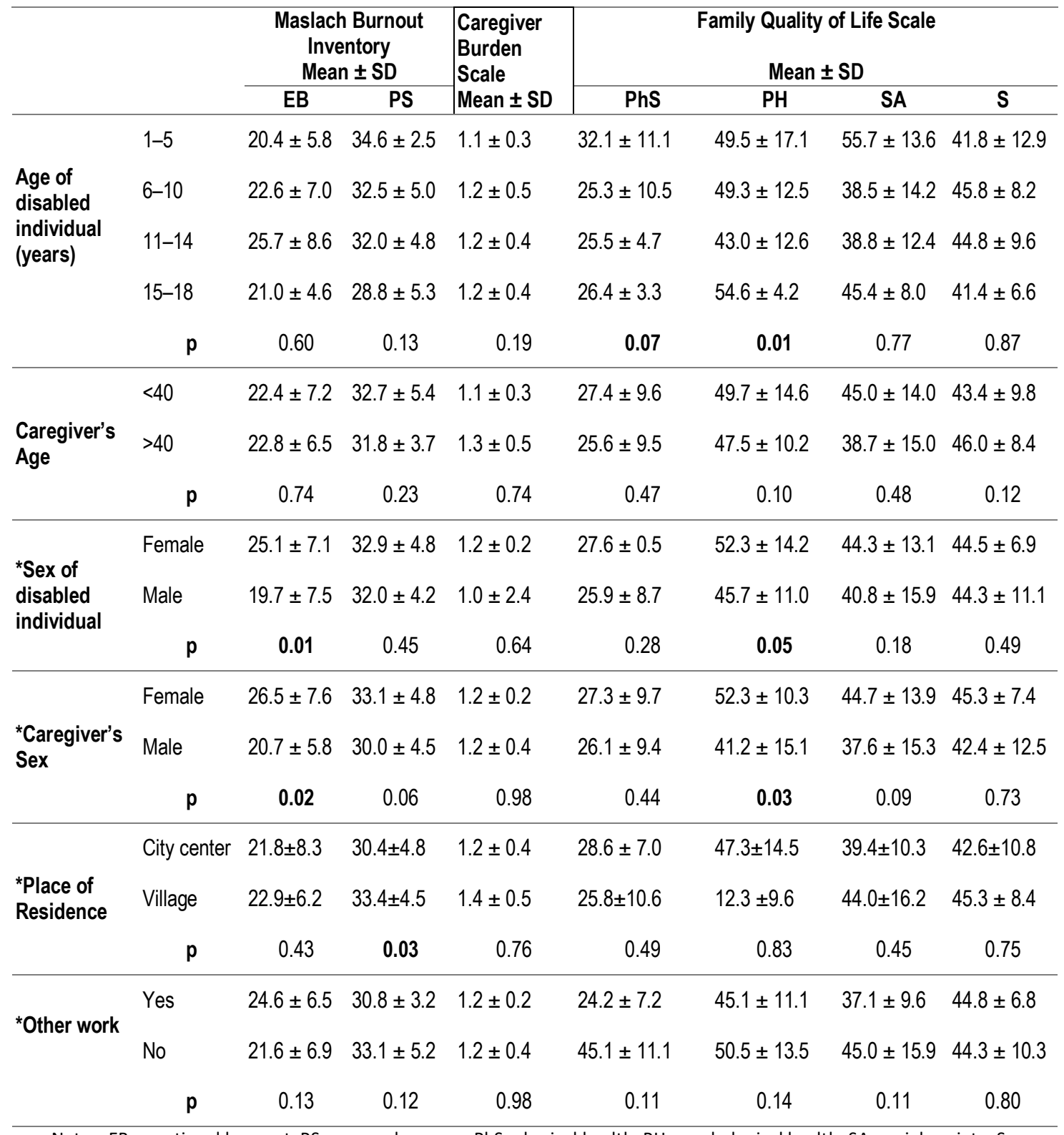

Notes: EB, emotional burnout; PS, personal success; PhS, physical health; PH, psychological health; SA, social anxiety; S, spiritual; SD, standard deviation; Kruskal-Wallis $\mathrm{H}$ test, *Mann-Whitney $\mathrm{U}$ test.

A significant difference was found between those who received home care and the Maslach Burnout Inventory personal success subscale $(\mathrm{p}=0.02)$ and between daily care of disabled individuals and the Quality of Life Scale physical health subscales $(\mathrm{p}=0.04$ and $\mathrm{p}=0.02$, respectively). There was a significant difference between the increase in caregiver income and the Maslach Burnout Inventory personal success subscale $(\mathrm{p}=0.04)$ (Table 4).

When comparing the sociodemographic data of the groups receiving and not receiving home care, a significant difference was found with adequate home care $(\mathrm{p}=0.00)$ (Table 5). 
Table 4. Comparison of clinical scales and sociodemographic data 2

\begin{tabular}{|c|c|c|c|c|c|c|c|c|}
\hline & \multicolumn{2}{|c|}{$\begin{array}{c}\text { Maslach } \\
\text { Burnout Inventory } \\
\text { Mean } \pm \text { SD }\end{array}$} & \multirow[t]{2}{*}{$\begin{array}{c}\text { Caregiver } \\
\text { Burden Scale } \\
\text { Mean } \pm \text { SD }\end{array}$} & \multicolumn{4}{|c|}{ Family Quality of Life Scale } \\
\hline & & EB & PS & & PhS & PH & SA & S \\
\hline \multirow{5}{*}{$\begin{array}{l}\text { Disability } \\
\text { Type }\end{array}$} & Physical & $22.2 \pm 6.9$ & $31.9 \pm 3.7$ & $1.1 \pm 0.3$ & $27 \pm 9.3$ & $51.8 \pm 9.0$ & $40.4 \pm 11.7$ & $46.5 \pm 6.0$ \\
\hline & Mental & $23.6 \pm 5.8$ & $31.7 \pm 5.2$ & $1.2 \pm 0.5$ & $24.5 \pm 7.4$ & $44.5 \pm 12.6$ & $41.0 \pm 15.7$ & $41.0 \pm 8.7$ \\
\hline & Speech & $32.0 \pm 4.2$ & $3.2 \pm 0.5$ & $1.0 \pm 0.2$ & 24 & 54 & 60 & 51 \\
\hline & Chronic & $22.6 \pm 6.9$ & $33.2 \pm 5.6$ & $1.3 \pm 0.5$ & $28.4 \pm 11.7$ & $48.8 \pm 16.7$ & $45.1 \pm 16.7$ & $44.5 \pm 12.3$ \\
\hline & $\mathrm{p}$ & 0.17 & 0.26 & 0.68 & 0.61 & 0.61 & 0.17 & 0.26 \\
\hline \multirow{3}{*}{$\begin{array}{l}\text { *Home Care } \\
\text { Services }\end{array}$} & Yes & $21.2 \pm 6.9$ & $33.5 \pm 4.9$ & $1.3 \pm 0.5$ & $25.6 \pm 9.1$ & $47.1 \pm 7.7$ & $42.3 \pm 10.6$ & $42.6 \pm 16.0$ \\
\hline & No & $23.0 \pm 6.9$ & $30.4 \pm 4.0$ & $1.1 \pm 0.3$ & $27.2 \pm 9.8$ & $49.5 \pm 14.4$ & $45.2 \pm 4.7$ & $44.1 \pm 10.5$ \\
\hline & $\mathrm{p}$ & 0.13 & 0.02 & 0.19 & 0.36 & 0.52 & 0.14 & 0.78 \\
\hline \multirow[t]{5}{*}{ Daily Care (H) } & $1-6$ & $29.0 \pm 11.1$ & $29.0 \pm 5.2$ & $2.0 \pm 1.0$ & $10.6 \pm 9.8$ & $22.3 \pm 11.9$ & $27.0 \pm 21.7$ & $36.3 \pm 9.8$ \\
\hline & $7-12$ & $20.1 \pm 5.6$ & $31.8 \pm 3.2$ & $1.1 \pm 0.3$ & $28.1 \pm 9.6$ & $50.8 \pm 4.2$ & $38.1 \pm 7.7$ & $45.4 \pm 6.9$ \\
\hline & $13-18$ & $23.7 \pm 6.2$ & $31.0 \pm 6.0$ & $1.1 \pm 0.3$ & $25.0 \pm 8.5$ & $45.3 \pm 12.3$ & $41.0 \pm 10.6$ & $42.6 \pm 7.3$ \\
\hline & $19-24$ & $22.3 \pm 6.9$ & $33.3 \pm 4.7$ & $1.2 \pm 0.4$ & $29.3 \pm 4.4$ & $52.0 \pm 11.9$ & $46.0 \pm 15.5$ & $45.5 \pm 10.2$ \\
\hline & $p$ & 0.50 & 0.32 & 0.13 & 0.04 & 0.02 & 0.25 & 0.33 \\
\hline \multirow{3}{*}{$\begin{array}{l}\text { *Social } \\
\text { Security }\end{array}$} & Yes & $22.8 \pm 6.9$ & $32.1 \pm 4.8$ & $1.1 \pm 0.4$ & $26.6 \pm 9.6$ & $48.6 \pm 13.2$ & $42.3 \pm 14.7$ & $44.2 \pm 9.5$ \\
\hline & No & $20.2 \pm 7.3$ & $34.8 \pm 3.8$ & $1.2 \pm 0.5$ & $27.4 \pm 10.4$ & $50.4 \pm 11.4$ & $44.6 \pm 15.1$ & $46.4 \pm 7.7$ \\
\hline & $p$ & 0.45 & 0.28 & 0.72 & 0.93 & 0.93 & 0.53 & 0.29 \\
\hline \multirow{4}{*}{$\begin{array}{l}\text { Monthly } \\
\text { Income } \\
\text { (TRY) }\end{array}$} & $0-2021$ & $22.3 \pm 7.4$ & $34.4 \pm 4.4$ & $1.3 \pm 0.5$ & $28.2 \pm 11.0$ & $48.8 \pm 14.6$ & $45.0 \pm 16.2$ & $44.5 \pm 12.7$ \\
\hline & $2022-500$ & $22.7 \pm 7.3$ & $32.0 \pm 4.7$ & $1.1 \pm 0.4$ & $25.6 \pm 10.1$ & $48.4 \pm 13.5$ & $39.8 \pm 14.3$ & $44.9 \pm 6.9$ \\
\hline & $>5000$ & $22.4 \pm 5.5$ & $29.8 \pm 4.5$ & $1.1 \pm 0.3$ & $26.7 \pm 9.5$ & $50.0 \pm 8.9$ & $45.0 \pm 12.3$ & $43.0 \pm 8.0$ \\
\hline & $p$ & 0.98 & 0.04 & 0.16 & 0.90 & 0.90 & 0.50 & 0.80 \\
\hline
\end{tabular}

Notes: EB, emotional burnout; PS, personal success; PhS, physical health; PH, psychological health; SA, social anxiety; S, spiritual; SD, standard deviation; Kruskal-Wallis $\mathrm{H}$ test, *Mann-Whitney $\mathrm{U}$ test.

Table 5. Comparison of home care services and sociodemographic data

\begin{tabular}{|c|c|c|c|}
\hline & $\begin{array}{l}\text { Home Care Services } \\
\text { Receiving Care (n) }\end{array}$ & $\begin{array}{l}\text { Home Care Services } \\
\text { Not Receiving Care (n) }\end{array}$ & $p$ \\
\hline \multicolumn{4}{|c|}{ Sex of Disabled Individual } \\
\hline Female & 6 & 17 & $0.17^{*}$ \\
\hline Male & 12 & 13 & \\
\hline \multicolumn{4}{|c|}{ Special Room for Disabled Individual } \\
\hline Yes & 14 & 13 & $0.12^{*}$ \\
\hline No & 4 & 17 & \\
\hline \multicolumn{4}{|c|}{ Is Home Care Sufficient? } \\
\hline Yes & 8 & 1 & $0.00^{* *}$ \\
\hline No & 10 & 29 & \\
\hline
\end{tabular}




\section{Discussion}

This study reviewed the health care utilization by individuals with severe disabilities using sociodemographic and demographic data. Caregiver burden and their quality of life, expectations, and needs were determined, and the factors affecting their satisfaction with health care were identified.

According to the Turkey Disability Survey, there were more males $(59.0 \%)$ than females (41.0\%) for all disability types (20). Durduran (2009) conducted a study and stated that $68.6 \%$ of the disabled individuals were male and $31.4 \%$ were female (24). Other studies have shown that $63.3-72 \%$ of the disabled children were male and 28-36.7\% were female (24-26). Our study, supported by other studies, found more disabled males than females, which suggested that disability is more of a risk for males. According to the Turkey Disability Survey (2002) and other reviewed studies that considered all age groups (27), a disability is likely to occur by the age of 10 years (24-26). Considering that individuals with severe disabilities were selected among those who applied to the health committee for government support, our study found that age of individuals who applied for support has tended to be <10 years. Several studies have indicated that $32.1-63.5 \%$ of disabilities are recognized within the first year of life $(17,25,28)$. Our data, which support that of similar studies, suggest that these disabilities may be inheritable and/or congenital.

Beşer et al. (2003) have stated that there were 48.1\% individuals, among 0-18 years old, with orthopedic disabilities (26). Another study found that there were 44.5\% individuals, among 0-18 years old, with mental disabilities, $36 \%$ with physical disabilities, $8 \%$ with hearing impairments, $7 \%$ with speech impairment, 3\% with visual impairment, and $1.5 \%$ with a chronic disease (29). One international study of children with disabilities $<7$ years old found $26.4 \%$ with neuromuscular diseases, $21.1 \%$ with severe psychiatric disorders, $9 \%$ with hearing impairment, and $4 \%$ with visual disorders (24). In our study, physical disability was most frequently observed among all disabilities. There may be differences in how disability types are determined because most studies did not limit the age groups to children, there are an insufficient number of studies on child disabilities and some studies conducted general evaluations using unstructured and different classifications to determine disability type.

Öztürk et al. (2017) have stated that $84 \%$ of caregivers are female, $44.2 \%$ are $41-55$ years old, and $1.2 \%$ are divorced (30). Some studies have shown that most caregivers are the mothers of the disabled children, are between 36 and 45 years old, and have families that break apart over time $(11,13)$. Our data are similar to those of these other studies. Considering the social role of women in the sociocultural structure of Turkey, it is expected that the caregivers be women. As people age, their expectations, attitudes, and behaviors become more consistent, which may be the reason that middleaged people are preferred as caregivers given that this role requires a great deal of responsibility for disabled individuals. Caregiving may negatively affect family relationships, such as causing disagreements with a spouse, living separately from a spouse, divorce, and increased tension.

Studies on children with physical disabilities and found a mean burden score between 27 points (low to none) and $40.70 \pm 6.87$ (low to moderate) $(29,30)$. Özdemir et al. (2009) have investigated the burden on mothers who are caregivers of a disabled child and found a caregiver mean burden score of $21.29 \pm$ 12 (little/none) (31). As in our study, the little/none mean scores for the burden on caregivers might have stemmed from their perception of helping patients rather than considering it a burden because of the value of Turkish cultural judgment.

One study has indicated that caregiving mothers of disabled children felt anxiety and were depressed, and as anxiety increased, their quality of life was negatively affected (32). Another study has indicated that parents of disabled children may experience cognitive changes, such as forgetfulness, attention deficit and concentration disorders, and changes in executive functions; and emotional changes, such as difficulty in controlling behavior, impulsivity, substance abuse, anger, unhappiness, despair, malaise, insomnia, and anxiety (11). The results of our study and other studies are similar, which suggests that well-being of caregivers who have difficulty coping with life events is affected and may result in psychological disorders (11-13).

Most studies did not show a significant difference between the age of the disabled individual and his or her quality of life $(19,33-35)$. However, as children age, mothers find it more difficult to cope with their child's problems and their hope for the future of the child is reduced as these problems recur and finally, their quality of life may deteriorate.

Duygun et al. (2003) have emphasized that parents who have a disabled daughter experience more emotional burnout than those with a disabled son (19). One study has compared caregiver burnout based on different types of disability and found that child's sex alone is not an effective factor; however, when combined with disability type, has an effect on the mother caregiver's emotional burnout, personal success, and anxiety scores (33). In contrast, other studies have indicated that the sex of the child and psychological disorders of mothers do not have an effect on the caregiver or child's

7 I P a g e

www.iiste.org 
quality of life $(19,34)$. Beşikçi (2000) has found that mothers who have a disabled daughter have more anxiety, which supports the results of our study and those of other studies (35). Compared to boys, daughters in Turkish culture are more protected and rearing is more traditional. Considering that even mothers who have a daughter showing normal development have anxiety about their daughter's future, it is natural that the mother of a disabled daughter feels even more anxiety because her daughter is more defenseless in many aspects.

In many cultures, mothers are preferred over other women in the family to be the caregivers. The reason for an unhealthy child is regarded as a failure of the mother; therefore, she is blamed for unhealthiness of the child by her relatives. This may lead to burnout and an impaired quality of the mother's life $(33,36)$.

Although disabled individuals and their families live in the district and urban areas (77.9\%) (30), no study has mentioned whether this contributes better quality life of individuals or their families; however, our study found that living in an urban area increases personal success and reduces burnout. Although additional studies using larger samples are needed to validate this.

Studies have shown that prolonged daily care is challenging for a caregiver's psychological and physical state (33-37). One study has indicated that mothers who did not have a caregiver assistant and prolonged daily care were more fatigued and emotionally burned out than those who had an assistant (33). Our study also found that prolonged daily care affects a caregiver's psychological and physical health. Sharing the burden of care with others helps mothers to relax and become more highly motivated to meet their child's needs, increases their own quality of life, and reduces their own burnout. Caring for disabled individuals is not limited to a single care, but also includes financial support. Socioeconomic well-being, such as an increased monthly income, social security, and social support, may reduce the burden on a caregiver (35-37). Similarly, our study showed that an increased monthly income and home care reduces caregiver burnout, and that income received for home care services increases caregiver satisfaction with the health care system.

Very few studies have investigated health care for severely disabled children or determined the levels of satisfaction, burnout, and quality of life of the caregivers. We believe that this study will provide helpful information for additional studies to be conducted on this subject. Satisfaction of both the disabled individuals and their caregivers can be increased by learning and evaluating the individuals' expectations, suggestions, and feedback using larger sample sizes and multicentric studies and by improving the quality of health care in all service processes.

\section{References}

1) World Health Organization. Basic documents. Geneva: WHO pub No: 57.8. Forty-fifth edition, 2006.

2) Somunoğlu S. "Sağlık-Sağlık Hizmetleri ve Türk Sağlık Sistemi”, Sağlık Kurumları Yönetimi1. Tatar M (ed). Eskişehir: 2012.

3) Öztüre A. Hasta Memnuniyeti Üzerine İstatistikî Analiz (Yüksek Lisans Tezi). Konya:, Selçuk Üniversitesi, Fen Bilimleri Enstitüsü; 2010.

4) Kavuncubaşı, Şahin, Yıldırım, Selami. Hastane ve Sağlık Kurumları Yönetimi. Ankara: Siyasal Kitabevi, 2012.

5) Bodur S, Durduran Y. Konya'da engelli çocukların sağlık hizmetlerinden yararlanma ve beklenti durumu. Genel Tip Derg 2009; 19(4):169-175.

6) Bilsin E, Başbakkal Z. Dünya ve Türkiye'de engelli çocuklar. Ege Üniversitesi Hemşirelik Fakültesi Dergisi 2014; 30 (2):65-78.

7) World Health Organization. Declaration of Alma-Ata. International Conference on Primary Health Care. Alma-Ata: 1978. www.who.int/hpr/NPH/docs/ declaration_almaata.pd

8) Akbaş E. Sağlık Hizmetlerinde Hasta Memnuniyeti ve Hasta Memnuniyetini Etkileyen Faktörler (Manisa Merkez Efendi Devlet Hastanesi Örneği) (Yüksek Lisans Tezi). İstanbul: 
Beykent Üniversitesi Sosyal Bilimler Enstitüsü İşletme Yönetimi Ana Bilim Dalı Hastane ve Sağlık Kurumları Yönetimi Bilim Dalı; 2014.

9) Altuntaş M, Yılmazer TT, Güçlü YA, Öngel K., Evde Sağlık Hizmeti Ve Günümüzdeki Uygulama Şekilleri; Tepecik Eğit Hast Derg 2010; 20(3):153-158.

10)Minnes P, Woodford L. Mediators and moderators of well-being in ageing family caregivers of adults with intellectual disabilities. IASSID World Congress Abstracts, Journal of Intellectual Disability Research, 2004: 48:370.

11)Glidden LM, Schoolcraft SA. Depression: its trajectory and correlates in mothers rearing children with intellectual disability. J Intellect Disabil Res 2003;47:250-263.

12)Şen E. Engelli Çocuğu Olan Ailelerin Yaşadığı Güçlükler (Yüksek Lisans Tezi). Mersin: Mersin Üniversitesi; 2004.

13)Özşenol F, Işıhan V, Ünay B, Aydın H., Akın R, Gökçay E. Engelli çocuğa sahip ailelerin aile işlevlerinin değerlendirilmesi. Gülhane Tıp Dergisi. 2003;45:156-164.

14)Altın AS. Engelli Evde Bakım Hizmetlerinde Ailenin Yeterliliği: Denizli Merkez İlçe Örnekleri (Dönem Projesi). Denizli: Pamukkale Üniversitesi; 2018.

15)Büyükşehir Belediyeleri Özürlü Hizmet Birimleri Yönetmeliği http://www.resmigazete.gov.tr/eskiler/2006/08/20060816-9.htm (12.02.2017)

(2006)

16)Herken H, Turan M, Şenol Ş. Down sendromlu çocuğu olan anne babaların depresyon düzeyleri ve depresyonla başa çıkma becerileri. Çocuk ve Gençlik Ruh Sağlığı Dergisi, 2000; 7:143-152.

17)Küllü Z. Özürlü Çocuğa Sahip Ebeveynlerde Depresyon Durumunun Değerlendirilmesi (Yüksek lisans tezi). Kayseri: Erciyes Üniversitesi; 2008.

18)Bertelli, M., Bianco, A., Rossi, M., Scuticchio, D., Brown, I. "Relationship between individual quality of life and family quality of life for people with intellectual disability living in Italy", J Intellect Disabil Res 2011;55(12): 1136-1150.

19)Duygun T, Sezgin N. "Zihinsel Engelli ve Sağlıklı Çocuk Annelerinde Stres Belirtileri Stresle Başa Çıkma Tarzları ve Algılanan Sosyal Desteğin Tükenmişlik Düzeyine Olan Etkisi”, Türk Psikoloji Dergisi, 2003; 18:37-52.

20)Kahriman İ, Bayat M. “Özürlü Çocuğa Sahip Ebeveynlerin Yaşadıkları Güçlükler ve Algıladıkları Sosyal Destek Düzeyleri”, Özveri Dergisi, 2009; 5:1.

21)Kaner S. Engelli Çocukları Olan Ana babaların Algıladıkları Stres, Sosyal Destek ve Yaşam Doyumlarının İncelenmesi (Bilimsel Araştırma Projeleri), Ankara: Ankara Üniversitesi; 2004.

22)İnci FH. Bakım Verme Yükü Ölçeği’nin Türkçe’ye Uyarlanması, Geçerlilik Ve Güvenilirliği (Yüksek Lisans Tezi). Denizli: Pamukkale Üniversitesi Sağlık Bilimleri Enstitüsü; 2006.

23)Okçin F. Kanser Hastasına Bakım Veren Aile Üyelerinin Yaşam Kalitesi Ölçeği Geçerlilik ve Güvenirlik Çalışması (Doktora Tezi). İzmir: Ege Üniversitesi Sağlık Bilimleri Enstitüsü; 2007.

24)Durduran Y. Engelli Çocukların Engellilikleri Dışındaki Sağlık Sorunları ve Sağlık Hizmetinden Yararlanma Durumları: Kontrollü Saha Çalışması (Doktora Tezi). Konya: Selçuk Üniversitesi; 2009.

25)Aktuğ E. Kocaeli ili Gölcük ilçesinde süreğen hastalık dışı özürlülük sıklığı, nedenleri ve özürlülerin sorunları (Yüksek Lisans Tezi). Kocaeli: Kocaeli Üniversitesi; 2008. 
26)Beşer E, Atasoylu G, Akgör Ş, Ergin F, Çullu E. Aydın il merkezinde özürlülük prevalansı, etyolojisi ve sosyal boyutu. TSK Koruyucu Hekimlik Bült 2006; 5:267-275.

27) Devlet İstatistik Enstitüsü (DİE). Türkiye Özürlüler Araştırması, Ankara, 2004.

28) Khamis V. Psychological distress among parents of children with mental retardation in the United Arab Emirates. Social Science Medicine 2007;64:850-857.

29)Bacıŏglu K, Özdemirercan T, Uzun Ş. Bartin ili özürlülüğün önlenmesi ve özürlü sorunlarına yönelik değerlendirme araştırması. Bartın Valiliği Aile Danışma Merkezi Müdürlüğü. 2006:23.

30)Öztürk YE, Şentürk Ş, Macit Y. Evde Bakım Hizmeti Alan Engelli Bireylere Sahip Ailelerin Bakım Verme Yüklerinin Belirlenmesi: Amasya Örneği. Türkiye Sosyal Hizmet Araştırma Dergisi 2017; 1(1):49-67

31) Özdemir FK, Şahin ZA, Küçük D. Kanserli çocuğu olan annelerin bakım verme yüklerinin belirlenmesi. Yeni Tip Dergisi 2009, 26: 153-8.

32)Bumin G, Günal A, Tükel Ş. "Anxiety, Depression And Quality Of Life in mothers of Disabled Children”. S.D.Ü. Tıp Fakültesi Dergisi 2008, 15(1); 611.

33) Kerns, A. K., Siklos, S. Assesing need for docil support in parents of children with autism and down syndrome. Journal Autism Developmental Disorder 2006;36; 921-933.

34)Ricci AL, Hodapp MR. Fathers of Children with Down's Syndrome Versus Other Types of Intellectual Disability: Perceptions, Stress, and Involment. J Intellect Disabil Res $2003 ; 47(4) ; 273-284$.

35) Beşikçi H. Otistik Olan ve Otistik Olmayan Normal Çocuklara Sahip Anne ve Babaların Kaygı Düzeyleri ve Aile Yapıları. (Yüksek Lisans Tezi). İstanbul: İstanbul Üniversitesi Sosyal Bilimler Enstitüsü; 2000.

36) Emerson E. Mothers of children and adolescents with intellectual disabilty: social and economic situation, mental health status, and the self assessed social and psychological impact of the child's difficulties. J Intellect Disabil Res 2003;47(4/5): 385-399.

37) Yayan EH. Metabolik sorunu olan çocuğun ebeveynlerinin bakım yükünün algılanan sosyal destek ve yaşam kalitelerine etkisinin incelenmesi (Yüksek Lisans Tezi). Malatya: İnönü Üniversitesi Sağlık Bilimleri Enstitüsü; 2018. 